\title{
Diachronic genre analysis: patterns of rhetorical organization in academic book reviews
}

\author{
Jorge Luis Queiroz CARVALHO • \\ Universidade do Estado do Rio Grande do Norte (UERN)
}

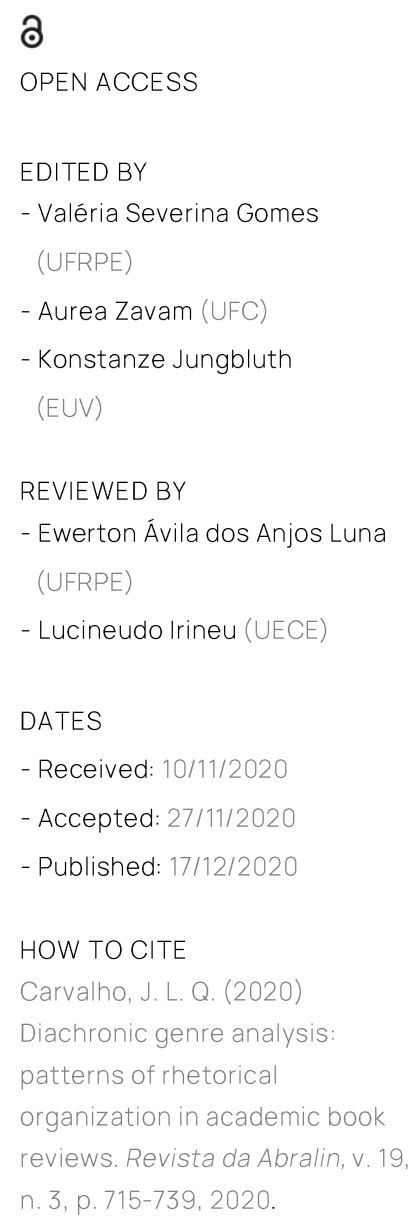

\section{ABSTRACT}

This study investigates vestiges of change and traces of permanence in academic book reviews produced between the $20^{\text {th }}$ and $21^{\text {st }}$ centuries. To this end, it aims to analyze the more frequent rhetorical moves in academic book reviews published between 1953 and 2015. The diachronic analysis covers a time continuum of 62 years which we divided in three generational phases: a) 1953-1970; b) 1971-2000; and c) 2001-2015. The division was based on the methodological parameters proposed by the Discursive Traditions paradigm. Each phase consists of 15 texts, adding up to a total of 45 samples that were collected from Brazilian scientific journals in the field of Languages and Linguistics. Epistemologically, we are based on the studies of John Swales (1990; 2004), as well as those of Motta-Roth (1995), Araújo (1996) and Bezerra (2001) to support the analysis of the rhetorical organization of reviews. In order to instrumentalize the diachronic analysis of genres, we found support in the works of Coseriu (1980), Zavam (2009), Castilho da Costa (2010) and other scholars in the already mentioned field of Discursive Traditions. The results have indicated four rhetorical moves present in the reviews: introducing to the book, summarizing the content, evaluating the book and issuing a final opinion. Those moves are divided in 16 rhetorical steps and their frequency and execution forms show traces of variation in each generational phase.

\section{RESUMO}

Este estudo analisa vestígios de mudança e traços de permanência em 


\section{REVISTA DA ABRALIN}

resenhas acadêmicas produzidas entre os séculos XX e XXI. Para tanto, tem por objetivo analisar os movimentos retórico-composicionais mais frequentes em resenhas acadêmicas publicadas entre 1953 e 2015. A análise diacrônica compreende um contínuo temporal de 62 anos que dividimos em três fases geracionais: a) 1953-1970; b) 1971-2000; e c) 2001-2015. A divisão tomou por base os parâmetros metodológicos propostos pelo paradigma das Tradições Discursivas. Cada fase é composta por 15 textos, somando um total de 45 exemplares que foram coletados em periódicos acadêmicos brasileiros da área de Letras e Linguística. Epistemologicamente, nos fundamentamos nos estudos de John Swales (1990; 2004), bem como em Motta-Roth (1995), Araújo (1996) e Bezerra (2001) para subsidiar a análise da organização retórica de resenhas. Para operacionalizar a análise diacrônica de gêneros, dialogamos com Coseriu (1980), Zavam (2009), Castilho da Costa (2010) e outros estudiosos do supracitado campo. Os resultados indicaram quatro movimentos retóricos presentes nas resenhas: introdução à obra, sumarização do conteúdo, avaliação da obra e avaliação final. Esses movimentos se dividem em 16 passos retóricos, cuja frequência e modos de realização apresentaram traços de variação em cada uma das fases geracionais.

\section{KEYWORDS}

Genre analysis. Discursive traditions. Rhetorical organization. Academic reviews.

\section{PALAVRAS-CHAVE}

Análise de gêneros. Tradições discursivas. Organização retórica. Resenha acadêmica.

\section{Introduction}

Research focused on the rhetorical analysis of genres in the academic domain has become an important and fructiferous niche for investigations, contributing not only to produce knowledge about the most diverse genres that have been analyzed over the past years, but also to build a teaching pedagogy based on them.

We may say that pioneering research, like the one of Swales (1990), have influenced an important investigative movement whose main concern was to identify how the genres are organized based on 


\section{REVISTA DA ABRALIN}

the recurrence of their rhetorical organization patterns. This applicability is observed in the wide variety of studies dedicated to investigate the moves and the rhetorical steps that constitute different artifacts of scientific communication.

The analytical framework outlined by Swales (1990) has proved to be productive for the analysis of different genres, especially those in the academic field. In this sense, stand out the researches that are been developed since the 90s, such as those conducted by Motta-Roth (1995), Araújo (1996; 2011) and Bezerra (2001), who have studied the rhetorical organization of academic book reviews, in addition to those by Motta-Roth and Hendges (1998), Biasi-Rodrigues (1998) and Araújo (1999), who analyzed abstracts. Different sections of the research project genre were recently investigated under this same field, like the rationale section, in the research of Oliveira and Alves-Filho (2017), and the one of methodology by Monteiro and Alves-Filho (2018).

The rhetorical structure was also the subject of Ciapuscio's (2006) studies about scientific articles. Her work related the analytical approach inspired by Swales (1990) to the paradigm of Discursive Traditions, with the purpose to describe the compositional model of the first scientific articles in the Linguistic field published in Argentina.

Similar to Ciapuscio (2006), in this study, we present a theoretical dialogue between the studies of genres based on John Swales (1990)'s perspective and the theoretical-methodological orientation of Discursive Traditions, field that instrumentalizes the study of genres in a diachronically oriented approach. Based on this theoretical intersection, we analyzed the evolutionary path of academic book reviews published in Brazil between the years of 1953 and 2015. We selected specifically texts published in Portuguese in Brazilian Linguistic journals.

Among the numerous studies that have already focused on aspects related to the structure of academic book reviews, we can highlight researches dedicated to observing the similarities and differences between academic reviews produced in different fields, such as the areas of Linguistics, Chemistry and Economics (MOTTA-ROTH, 1995). Other studies have also investigated the differences between academic reviews produced by experts and by novice researchers (BEZERRA, 2001). We even point out the research on the differences in the use of evaluation strategies in academic reviews produced by students from Brazilian and American universities (ARAÚJO, 2011).

Despite the great relevance of those contributions, we agree with Motta-Roth (1995, p. 291) that "other interesting questions have to do with diachronic studies concerning the origins of academic genres". Thereby, we noticed that, although the referred genre has already been the subject of different reflections, there is still a gap regarding the investigation of how it and the other genres of the academic sphere were historically constituted.

This study is also justified by the perception that the rhetorical action of reviewing is present and is significant for the Brazilian academic community of Linguistics since the first periodical publications in that area started, in the 50s decade. Despite being a genre already described by other analysts, we believe that the researches that have explored it have not exhausted its possibilities for analysis, but rather offer important subsidies for its characterization in specific synchronisms. This 


\section{REVISTA DA ABRALIN}

study, thus, aims to go beyond the analysis of this synchronic axis, in order to investigate its diachronic path.

The reviews published in the past century have also aroused research interest due to the fact that we noticed how significant they were for the academic community at the time. It could be evidenced when looking at the large number of reviews that were published by issue in academic journals in the area of Languages ${ }^{1}$ and Linguistics in the middle of the $20^{\text {th }}$ century. Most journals from that period used to publish dozens of copies by issue, while after the mid-80s, this number decreased considerably, given priority to the publication of scientific articles.

This initial observation about the relevance of academic reviews to the area of Languages and Linguistics in the Brazilian context of the 1950s, contrasts with the fact that, nowadays, it has been defined as a genre of small expression in the academy (MOTTA-ROTH, 1995). Our investigation, however, takes into account the fact that our study object is associated with social situations that have also undergone different transformations and that, possibly, this genre have not always presented a character of small expressiveness. Our study, thus, aims to describe the rhetorical-compositional changes this genre has gone through during the time continuum of 62 years.

However, regardless of its status, it is known that the book review is, until today, an essential genre for its field as it aims to influence the academic community to accept a book or other academic production as a valid reading or not (ARAÚJO, 1996). Thus, it is a genre that presents a paradox between having little expression, since it is rarely cited as a reference in articles and/or books, but, at the same time, carries the great persuasive power of influencing experts and students to read (or not) certain intellectual productions.

This characteristic has caught our attention by the fact that, although currently there are genres with more prestige in the academy, the book reviews still occupy a prominent space there. This is verified by observing that none of the other academic genres present communicative purposes or social functions that are similar or competing with theirs. Besides that, this genre remains present in several specialized journals, as well as in the university context of the reading and text production classes. The permanence of this genre in the educational environment is due to the potential that it can have in stimulating students' critical sense and the evaluative ability.

Thus, this article aims to analyze the most frequent rhetorical moves in academic reviews published between 1953 and 2015. The analysis will be operationalized through the division of three synchronisms that will cover three generational phases: i) 1953-1970; ii) 1971-2000; and iii) 20012015. Therefore, the work will be divided, in addition to this introduction, as follows: a) the conceptual foundations that support this research, that is: the studies in Discursive Traditions and the perspective of the rhetorical structure analysis of genre; b) the methodological procedures of

\footnotetext{
${ }^{1}$ The translation of the expression Letras (Letters), from Brazilian Portuguese, was adopted as Languages for lack of expression with equivalent semantic content in English language. Bearing in mind that, in the Brazilian context, "Letters" is a great field of knowledge, which includes the studies of Linguistics, Literature, as well as Portuguese and foreign languages. So that Brazilian students who intend to work as teachers or researchers in the areas previously mentioned must have a college degree in Letras.
} 


\section{REVISTA DA ABRALIN}

analysis and data gathering; and, finally, d) the conclusion of the article, where we will resume the main findings.

\section{Theoretical background}

The notion of Discursive Traditions, however relatively recent, goes back to a series of assertions that have been elaborated since 1980 within the scope of the German Pragmatic Philology that make it possible for us to understand how linguistic elements as well as genres and discursive aspects of language transform and establish themselves throughout their various synchronisms.

As a theoretical paradigm, the studies in Discursive Traditions are based on the conceptions of Coseriu (1980), who resumed Humboldt's propositions to say that the language production is not a finished product (ergon), but an activity in constant performance (enérgeia). The Greek expressions indicate an adherence to the Aristotelian thought, that defines energéia as an endless creative activity. The realization of language, in this sense, is understood in two ways: as a product - from the synchronic perspective -, or as an uninterrupted process - according to a diachronic bias. This concept was initially borrowed by the Discursive Traditions Paradigm to study the language, however, Coseriu (1980) extended this discussion to the analysis of objects more related to text and discourse studies. In this sense, the studies in this field are also dedicated to analyze genres, understanding them as part of an uninterrupted historical process, in which they undergo different changes throughout the historical course.

When analyzing objects of a more complex nature, such as genres, the studies in Discursive Traditions have commonly adopted an integrative perspective, in which incorporate the contributions of other theoretical perspectives. In this study, we will resort to the studies of Swales (1990; 2004) to support the understanding of genres and rhetorical structure analysis.

Swales (1990) understands the genre as a class of communicative events that have the same purposes and are recognized by the members of a discursive community. This notion of genre involves an apparatus of crucial concepts to its understanding, among which stand out as pertinent to genre analysis the notions of discursive community, communicative purpose and rhetorical structure. Our work will focus on the last of these notions.

The studies about how the academic genres are organized based on their rhetorical structures, as we discussed earlier, found fertile ground after Swales's research (1990). Examining the organizational patterns of introductions in scientific articles, the author elaborated the Creating A Research Space (CARS) Model. This model resulted from the analysis of different samples of research article introductions from different areas in which the author drafts three rhetorical moves that we present below: 


\section{REVISTA DA ABRALIN}

\section{MOVE 1: ESTABLISHING A TERRITORY}

Step 1 - Claiming importance of the research

Step 2 - Making topic generalizations

Step 3 - Reviewing items of previous research

\section{MOVE 2: ESTABLISHING A NICHE}

Step 1A - Counter-claiming

Step 1B - Indicating gaps

Step 1C - Question-raising

Step 1D - Continuing a tradition

\section{MOVE 3: OCCUPYING THE NICHE}

Step 1A - Outlining purposes

or and/or

and/or

Step 1B - Announcing present research

Step 2 - Announcing principle findings

Step 3 - Indicating article structure

In Chart 1, we present the three moves that are part of the introduction of academic articles: 1) Establishing a territory; 2) Establishing a niche; e 3) Occupying the niche. Each of them has subdivisions that the author calls steps. We highlight that not all the rhetorical moves and steps were present in all the research article introductions analyzed by him. Given that the author considers genres as objects that oscillate between permanence and flexibility, the CARS model consists in a descriptive and non-prescriptive model about the rhetorical patterns and gave rise to a series of studies about the rhetorical structure of genres.

Swales (2004) pointed out that the rhetorical moves perform communicative functions in genres and that their delimitation criteria are intuitive and functional. Paltridge (2009, p. 71), on the other hand, understands that these communicative units must be delimited taking into account the identification of their semantic attributes and, above all, using categories essentially based on content, and not on the way the content is linguistically expressed.

The CARS model was the pioneer of several studies, among which we understand as pertinent to our work the models of rhetorical organization of academic book reviews. The models proposed from analyzes such as those of Motta-Roth (1995), Araújo (1996) and Bezerra (2001) are detailed in the chart below: 


\section{REVISTA DA ABRALIN}

\begin{tabular}{|c|c|c|}
\hline $\begin{array}{l}\text { MOTTA-ROTH MODEL } \\
\text { (1995) }\end{array}$ & ARAÚJO MODEL (1996) & BEZERRA MODEL (2001) \\
\hline M1. Introducing the book & M1. Establishing the field & M1. Introducing the work \\
\hline $\begin{array}{l}1 \text { - Defining the general topic } \\
\text { of the book } \\
2 \text { - Informing about potential } \\
\text { readership } \\
3-\text { Informing about the } \\
\text { author } \\
4 \quad-\text { Making topic } \\
\text { generalizations } \\
5 \text { - Inserting book in the field }\end{array}$ & $\begin{array}{l}1 \text { - Making topic generalizations } \\
2 \text { - Claiming centrality } \\
3 \text { - Indicating the intended } \\
\text { audience } \\
4 \text { - Informing the reader about } \\
\text { the origin of the book } \\
5 \text { - Stating the aim of the book } \\
6-\text { Referring to previous } \\
\text { publications }\end{array}$ & $\begin{array}{l}1 \text { - Making topic generalizations } \\
2 \text { - Arguing about the relevance of } \\
\text { the book } \\
3 \text { - Informing about the author } \\
4 \text { - Making topic generalizations } \\
5 \text { - Informing about the origin of } \\
\text { the work } \\
6-\text { Referring to previous } \\
\text { publications }\end{array}$ \\
\hline M2. Outlining the book & M2. Summarizing the content & M2. Summarizing the work \\
\hline $\begin{array}{l}6 \text { - Providing general view of } \\
\text { the organization of the book } \\
7 \text { - Stating the topic of each } \\
\text { chapter } \\
8 \text { - Citing extra-text material }\end{array}$ & $\begin{array}{l}7 \text { - Describing the organization } \\
\text { of the book } \\
8 \text { - Reporting/discussing the } \\
\text { content of the book } \\
9 \text { - Evaluating the book }\end{array}$ & $\begin{array}{l}7-\text { Describing the organization of } \\
\text { the book } \\
8-\text { Presenting/ discussing the } \\
\text { content } \\
9 \text { - Citing extra-text material }\end{array}$ \\
\hline $\begin{array}{l}\text { M3. Highlighting parts of the } \\
\text { book }\end{array}$ & improvement & M3. Criticizing the book \\
\hline $\begin{array}{l}9-\text { Providing focused } \\
\text { evaluation }\end{array}$ & & $\begin{array}{l}19 \quad-\quad \text { Evaluating } \\
\text { positively/negatively } \\
11-\text { Pointing out editorial issues }\end{array}$ \\
\hline $\begin{array}{l}\text { M4. Final closing evaluation } \\
\text { of the book }\end{array}$ & $\begin{array}{l}\text { M3. Providing final assessment } \\
\text { of the book }\end{array}$ & $\begin{array}{l}\text { M4. Completing the analysis of the } \\
\text { book }\end{array}$ \\
\hline $\begin{array}{l}10 \mathrm{~A}- \\
\text { recommending/disqualifying } \\
\text { the book } \\
10 \mathrm{~B}-\text { Recommending the } \\
\text { book despite indicated } \\
\text { shortcomings }\end{array}$ & $\begin{array}{l}11 \\
\text { Recommending/disqualifying } \\
\text { the book } \\
12-\text { Making suggestions for } \\
\text { future applications }\end{array}$ & $\begin{array}{l}12 \mathrm{~A}-\text { Recommending the book } \\
\text { completely } \\
12 \mathrm{~B}-\text { Recommending the book } \\
\text { despite indicating limitations } \\
13 \text { - Informing about potential } \\
\text { readership }\end{array}$ \\
\hline
\end{tabular}

CHART 2 - Rhetorical structure of academic reviews. Source: Motta-Roth (1995), Araújo (1996) and Bezerra (2001).

These models will be useful in our work because they present both points of convergence and divergence and make it possible to intensify the debate about the rhetorical organization of reviews. 


\section{REVISTA DA ABRALIN}

It should be noted, however, that these models will guide our analysis, but they are not delimiting and, therefore, we do not rely exclusively on them, as we believe it is possible to identify different rhetorical moves and steps in texts published both in the past and in the present, as well as launch our own interpretation of them.

\section{Methodology}

Given our interest in analyzing the constitution of the genre mentioned since the beginning of its circulation in a specific area, we gathered a corpus of 45 academic reviews in the field of Linguistics published between the years of 1953 and 2015. This material was divided in three generations, each one corresponding to a period of time equivalent to thirty years. Starting from there, we have gathered fifteen texts for each generation. We decided to collect the texts produced from the 50s of the last century since that is the decade that marks the inauguration of periodic academic publication in Brazil focused on our area of interest and that precedes the institutionalization of Linguistics as an academic discipline in the country.

Thereby, for the formation of the corpus we delimited some selection criteria. To make the gathering viable, we selected texts published in journals whose collection were available on internet pages. From these journals, we have chosen samples that discuss works of Linguistics, in order to conduct an analysis of the genre since the beginning of its circulation in a field of knowledge. In addition, we have given priority to texts produced by different authors as a way to ensure that the individual styles of reviewers would not directly interfere in the results, given that we are interested in examining the constitutive characteristics of the genre itself and not the elements of a more subjective nature.

The corpus gathering was made using the indirect documentation technique and from consultations to bibliographic sources, since the texts were already written and published in academic journals of free access. Furthermore, as Gil (2008) points out, compilation of data through bibliographic research is indispensable for historical studies. In the case of our study, this technique was adopted due to the fact that only through consulting published and socially distributed journals at different times we could gather the material necessary to carry out this investigative work.

As a form of ensuring that our corpus would be formed by samples produced within the established period of time, we collected the data that were available on reliable sources such as the journals websites and the SciELO digital library. Therefore, among the pioneering academic journals that present at least one section dedicated to the publication of reviews, we have chosen journals such as Letras (UFPR) and Alfa (UNESP), whose first issues date, respectively, from the years of 1953 and 1962. These journals have made their entire archive available online and served as a source for the gathering of the corpus. 


\section{REVISTA DA ABRALIN}

In addition to these two journals, we collected samples from journals that were launched in the 80s and 90s, such as Documentação de Estudos em Linguística Teórica e Aplicada - D.E.L.T.A². (PUCSP), that is published since 1985, and Filologia e Linguística Portuguesa - FLP ${ }^{3}$ (USP), that have made their issues available on the internet since 1997. The reviews from all the four journals were originally written and published in Portuguese although some examples from the texts were translated to English in this article order to exemplify some rhetorical moves and steps identified throughout the study.

The corpus of 45 texts was divided in three generational phases. We have adopted this division considering what has been applied in other research on DT which start from the principle that this gap "represents a life generation, estimated time for changes to occur" (CASTILHO DA COSTA, 2010, p. 4). In our analysis we investigated a time lapse of 62 years and, even though collected only texts produced starting from 1953, we have followed Zavam's characterization (2009), according to which the $20^{\text {th }}$ century can be divided in three generational periods: a) 1901 - 1940; b) 1941 - 1970 and c) 1971 - 2000. Our corpus also includes the texts produced in the first half of the $20^{\text {th }}$ century, that is: 20012015. Therefore, the data from the first generation cover the continuum of sixteen years (1953-1970); with regard to the second generation, we were able to gather data that cover the thirty years equivalent to that phase (1971-2000) and, finally, the third generation covers the first decade and a half from the $21^{\text {st }}$ century (2001-2015). The data of the first generation correspond to the manifestations of the genre published in the journals Letras ${ }^{4}$ and $A l f a^{5}$, considering that the journals D.E.L.T.A. ${ }^{6}$ and $\mathrm{FLP}^{7}$ emerged in the decades of 1980 and 1990 and, therefore, form the base of the second and third generational periods along with Letras and Alfa.

The following chart shows the way how each generational phase covered by this research is represented, indicating the years in which the samples were collected:

\footnotetext{
${ }^{2}$ Documentation of Studies in Theoretical and Applied Linguistics - DSTAL

${ }^{3}$ Philology and Portuguese Linguistics - PPL

${ }^{4}$ Available from https://revistas.ufpr.br/letras/issue/archive. [Accessed 11 April 2016]

${ }^{5}$ Available from https://periodicos.fclar.unesp.br/alfa/issue/archive/4 [Accessed 11 April 2016]

${ }^{6}$ Available from https://revistas.pucsp.br/index.php/delta/issue/archive [Accessed 11 April 2016]

${ }^{7}$ Available from http://www.revistas.usp.br/flp/issue/archive/5 [Accessed 11 April 2016]
} 


\section{REVISTA DA ABRALIN}

\begin{tabular}{|c|c|}
\hline Generational phases & $\begin{array}{l}\text { Years when the samples were } \\
\text { published }\end{array}$ \\
\hline $\begin{array}{l}\text { Phase } 1-20^{\text {th }} \mathbf{c} . \\
(1953-1970)\end{array}$ & $\begin{array}{l}\text { 1953, 1954, 1957, 1958, 1959, 1960, } \\
\text { 1961, 1962, 1963, 1969, } 1970 .\end{array}$ \\
\hline $\begin{array}{l}\text { Phase } 2-2^{\text {th }} \mathbf{c} \\
\quad(1971-2000)\end{array}$ & $\begin{array}{l}\text { 1971, 1975, 1980, 1981, 1982, 1985, } \\
\text { 1987, 1989, 1991, 1995, 1997, 1998, } \\
\text { 1999, 2000. }\end{array}$ \\
\hline $\begin{array}{l}\text { Phase } 3 \text {-21 } \\
\text { (2001- } 2015)\end{array}$ & $\begin{array}{l}2001,2002,2003,2004,2005, \\
2006,2007,2008,2009,2010, \\
2011,2012,2013,2014,2015\end{array}$ \\
\hline
\end{tabular}

CHART 3 - Distribution of the generational phases and years when the samples were published

In order to keep this material organized and to facilitate the recognition of each one of the samples, we codified the corpus by naming and assigning to each text: a) the letter R, which indicates Review; b) a number indicating the order in which each review was published in relation to the other texts; and c) the year of publication. This coding will be also used in the analysis section where we show examples from the corpus so that we can indicate the text to which we refer. Thus, "R01-1953" refers to the first academic review published among the ones that were collected and "1953" indicates the year of this publication, "R45-2015", by its turn, indicates the forty-fifth view collected and the year of publication is 2015 and so on.

\section{Analysis}

As we have already stated, our analysis is based on the models of rhetorical organization produced by Motta-Roth (1995), Araújo (1996) and Bezerra (2001), seeking convenient meeting points and that fit the specificities of the academic book reviews we have taken as our study object. It should be noted that some of the rhetorical moves and steps we have analyzed here do not find equivalents in the work of these authors and some others have suffered adaptations according to what the data in this study revealed.

The analysis has shown that the rhetorical structure of the samples has four moves: 


\section{REVISTA DA ABRALIN}

Move 1 - Introducing the book

Move 2 - Summarizing the content

Move 3 - Evaluating the book

Move 4 - Issuing a final opinion

CHART 4 - Rhetorical structure of academic book reviews

The first move, called Introducing the book, regards the content inside the initial paragraphs of the reviews. The topics that state it provide information related to the subject and to the origin of the book reviewed, authors, the targeted audience and the research area in which it is inserted. It is important to make it clear that these information represent a favorable occasion for the reviewer to build his own space within the academic environment (BEZERRA, 2001). In order to do that, the reviewer uses some strategies that project him as an informed subject about what happens in the academic scenario, such as: suggest familiarity with the author of the book, show knowledge about other publications in the area and indicate gaps in the line of research to demarcate how the book fills them. Move 1 is the most typical of academic reviews, along with Move 2.

The second rhetorical move, Summarizing the book, normally presents an overview of the general organization of the book, the topics of each chapter, the research methodology adopted by the author of the book, as well as offering a discussion on the content. On some occasions, although less frequently, the reviewers approach materials that are not necessarily concerned with the content of the publication, dealing with graphics, rates, charts and bibliography. Based on this observation, we can say that this move has a strong descriptive feature, even though it anticipates the evaluation of the work that gains clearer outlines from the third move identified for this genre.

Throughout the Move 3, the reviewer most clearly marks his evaluative positions by an analysis directed at certain points in the text or an evaluation of the overall plan of the publication. When Evaluating the book, some improvement suggestions are highlighted intending to indicate aspects that can be improved or revised. Evaluations do not always focus on negative criticism, but also on recommendations, highlighting the positive aspects and comparisons with other publications. Although it was not so frequent in the first generational phase, this component of the reviews has a high frequency in the later phases.

In regard to the fourth move, Issuing a final opinion, we observed the prescriptive character of the academic book reviews, as they make recommendations or disqualifications of the book, designating whether the reading is valid or not. On the other hand, it must be mentioned that it does not always focus on assessment. The results in the first generational phase showed us peculiar characteristics of this constituent, especially when we it is compared to the most recent reviews. At the beginning of the circulation of this genre, we noticed that encouragement statements for future publications were transmitted, which suggested that the reviewers while revealing politeness were concerned with expressing cordiality in the critiques and/or suggestions and as well as with the productivity in their field of studies. 


\section{REVISTA DA ABRALIN}

Regarding the recurrence of each of these rhetorical moves, we created the chart below, that illustrates the number of occurrences $(\mathrm{O})$ and the frequency $(\%)$ in each generational phase:

\begin{tabular}{|c|c|c|c|c|c|c|}
\hline \multirow{2}{*}{ RHETORICAL MOVES } & \multicolumn{2}{|c|}{ Phase 1 } & \multicolumn{2}{c|}{ Phase 2 } & \multicolumn{2}{c|}{ Phase 3 } \\
\cline { 2 - 6 } & $\mathbf{0}$ & $\%$ & $\mathbf{0}$ & $\%$ & O & $\%$ \\
\hline $\begin{array}{c}\text { Move 1. } \\
\text { Introducing the book }\end{array}$ & 15 & $100 \%$ & 14 & $93.3 \%$ & 15 & $100 \%$ \\
\hline $\begin{array}{c}\text { Move 2. } \\
\text { Summarizing the content }\end{array}$ & 14 & $93.3 \%$ & 15 & $100 \%$ & 15 & $100 \%$ \\
\hline $\begin{array}{c}\text { Move 3. } \\
\text { Evaluating the book }\end{array}$ & 11 & $73.3 \%$ & 14 & $93.3 \%$ & 14 & $93.3 \%$ \\
\hline $\begin{array}{c}\text { Move 4. } \\
\text { Issuing a final opinion }\end{array}$ & 12 & $80 \%$ & 11 & $73.3 \%$ & 14 & $93.3 \%$ \\
\hline
\end{tabular}

CHART 5 - Frequency of the rhetorical moves of the reviews in each generational phase.

As noted, in Phase 1, the Move 1 - Introduction of the book was the most recurrent move, being present in all the reviews collected for that period. Move 2 - Summarizing the content was the second more prototypical, accounting for $93.3 \%$ of the cases. The Move 3 - Evaluating the book and the Move 4 - Issuing a final opinion are characteristics that do not present the same rates as the other components in Phase 1, considering that they were present in $73.3 \%$ and $80 \%$ of the samples, respectively. In the second generational phase, the most recurrent move was the one regarding the summary of the content (Move 2), appearing in $100 \%$ of the cases. The introduction (Move 1) and the evaluation (Move 3) reached high levels, being recurrent in 93.3\% of the academic reviews published between 1971 and 2001, while the final opinion (Move 4) on whether the book was worth reading or not was recurrent in $73.3 \%$ of the samples. Phase 3 is the one we found the greatest percentage of distribution of the rhetorical organization, given that the Moves 1 and 2 were updated in $100 \%$ of the cases, while Moves 3 and 4 appear in $93.4 \%$ of the reviews.

Each one of these moves is composed of different steps, which are rhetorical components of a lower hierarchy. With regard to these components, we present in Chart 6 the descriptive pattern with all the steps found in the corpus of this study: 


\section{REVISTA DA ABRALIN}

\begin{tabular}{|c|c|c|c|c|c|c|}
\hline \multirow{2}{*}{ RHETORICAL STRUCTURE } & \multicolumn{2}{|c|}{ Phase 1} & \multicolumn{2}{|c|}{ Phase 2} & \multicolumn{2}{|c|}{ Phase 3} \\
\hline & $\mathbf{0}$ & $\%$ & $\mathbf{O}$ & $\%$ & $\mathbf{0}$ & $\%$ \\
\hline MOVE 1 - Introducing the book & 15 & $100 \%$ & 14 & $93.3 \%$ & 15 & $100 \%$ \\
\hline Step 1.1 - Making topic generalizations & 8 & $53.3 \%$ & 6 & $40 \%$ & 6 & $40 \%$ \\
\hline 1.2 - Defining the general topic of the book & 8 & $53.3 \%$ & 8 & $53.3 \%$ & 7 & $46.6 \%$ \\
\hline 1.3 - Informing about the author & 9 & $60 \%$ & 8 & $53.3 \%$ & 7 & $46.6 \%$ \\
\hline 1.4 - Informing about potential readership & 9 & $60 \%$ & 5 & $33.3 \%$ & 6 & $40 \%$ \\
\hline 1.5 - Informing the origin of the book & 5 & $33.3 \%$ & 4 & $26.6 \%$ & 5 & $33.3 \%$ \\
\hline 1.6 - Inserting book in the field & 8 & $53.3 \%$ & 8 & $53.3 \%$ & 9 & $60 \%$ \\
\hline MOVE 2 - Summarizing the content & 14 & $93.3 \%$ & 15 & $100 \%$ & 15 & $100 \%$ \\
\hline 2.1 - Describing the overall organization & 8 & $53.3 \%$ & 11 & $73.3 \%$ & 10 & $66.6 \%$ \\
\hline 2.2 - Presenting the topics of the book & 8 & $53.3 \%$ & 9 & $60 \%$ & 14 & $93.3 \%$ \\
\hline 2.3 - Discussing the content of the book & 9 & $60 \%$ & 13 & $86.6 \%$ & 14 & $93.3 \%$ \\
\hline 2.4 - Reporting the methodology & 7 & $46.6 \%$ & 2 & $13.3 \%$ & 3 & $20 \%$ \\
\hline 2.5 - Citing extra-text material & 3 & $20 \%$ & 2 & $13.3 \%$ & 4 & $26.6 \%$ \\
\hline MOVE 3 - Evaluating the book & 11 & $73.3 \%$ & 14 & 93.3\% & 14 & $93.3 \%$ \\
\hline 3.1 - Providing general assessment & 6 & $40 \%$ & 13 & $86.6 \%$ & 11 & $73.3 \%$ \\
\hline 3.2 - Providing focused assessment & 9 & $60 \%$ & 6 & $40 \%$ & 7 & $46.6 \%$ \\
\hline $\begin{array}{llll}3.3-\quad \text { Presenting } & \text { suggestions } & \text { for } \\
\text { improvement } & & \\
\end{array}$ & 7 & $46.6 \%$ & 5 & $33.3 \%$ & 3 & $20 \%$ \\
\hline MOVE 4 - Issuing a final opinion & 12 & $80 \%$ & 11 & $73.3 \%$ & 14 & $93.3 \%$ \\
\hline 4.1 - Recommending/disqualifying the book & 5 & $33.3 \%$ & 10 & $66.6 \%$ & 14 & $93.3 \%$ \\
\hline $\begin{array}{l}4.2-\text { Expressing wishes for future } \\
\text { publication }\end{array}$ & 7 & $46.6 \%$ & 1 & 6.6 & - & - \\
\hline
\end{tabular}

CHART 6 - Rhetorical moves and steps of academic reviews in three generations

As we can see, academic reviews are accomplished through different components that are grouped in four moves and sixteen steps. According to Kabatek (2006), each traditional aspect of the texts and genre - we may include the rhetorical moves and steps - acquire a significant value due to their frequency. Considering that some moves and steps are more frequent than others, we can assume that some of them are more traditional or, in other others, more prototypical according to a Swales' point of view (1990). Although each of these components is numbered, it must be made clear that they are not arranged in the reviews in a specific sequence and, therefore, the numbering is attributed as a way of distinguishing them and not ordering them. Over the next paragraphs, we describe this rhetorical structure in more details. 


\section{REVISTA DA ABRALIN}

\subsection{Move 1 - Introducing the book}

The Move 1 - Introducing the book, concerns the content provided in the initial paragraphs of the book reviews. The reviewers may mobilize six different rhetorical steps that present various types of information. These six compositional elements have been recurrent in the three generations and appear to inform the topics covered in the books; information about the authors; targeted audience; origin; as well as to indicate the field in which the book is inserted. We will, from now on, focus on the description of each step.

Step 1.1 - Making topic generalizations, for example, is one of the most recurrent ways for introducing the book. This step takes place when the reviewer presents general information related to the subject matter of the reviewed work. We named this compositional item after the CARS model, by Swales (1990), who forged the term to refer to ways of introducing content impartially. Although Swales (1990) have identified it in the analysis of scientific articles, other researchers, when investigating the reviews, adopted the same term to refer to the textual portions that indicate the main subject of the book (ARAÚJO, 1996) and that provide information about its context of publication (MOTTA-ROTH, 1995).

Our data revealed that, when making generalizations about the topic, the reviewers are concerned with introducing the book based on some argumentative strategies, such as: exposition of previous information; indicating the importance of the book, as well as pointing out the gaps and difficulties by the discursive community to produce and have access to academic publication. We can observe some examples in the following excerpts:

(Excerpt \#1) Unfortunately, publications in the North and Northeast of the country do not reach us easily, so that the faculty members of the Portuguese team at the State School of Ceará can only now be read and judged with admiration and respect by many professors in our academic discipline. (R04_1957)

(\#2) It is not so common, in Discourse Analysis, that the same work can reunite an original and rigorous theoretical formulation to a broad and cautious corpus survey and analysis (R38_2008)

In the samples of reviews published in the first two generational phases (1953 to 1970 and 1971 to 2000), the informative focus was on showing that language studies were beginning to overcome difficulties related to access to academic publications, as we can see from the Excerpt \#1. The Excerpt \#2, from the third generation (2000 to 2015), on the other hand shows a focus more on describing the state of the art - the same strategy was identified in examples from Phase 2. In both cases shown, topic generalizations are made to introduce the book. Regarding the frequency, the Chart 6 illustrates that this informational unit was more frequently found in samples of the first generation, that is, in $53.3 \%$ of the analyzed texts. In generational phases 2 and 3 , the presence occurred in $40 \%$ of the reviews. 


\section{REVISTA DA ABRALIN}

Step 1.2 - Defining the general topic of the work, deals specifically with the thematic content of the publication instead of contextual information. When analyzing the diachronic path of the genre, we detected that this second step has not undergone significant changes, maintaining a regular frequency in the three generations considering that, in both the first and the second phases, it was found in 8 of the 15 samples collected. This means a manifestation in $53.3 \%$ of the texts that correspond to each group. In the third generation, it could be identified in 7 reviews, making up $46.6 \%$ of the material gathered from this phase.

This component can be exemplified in the excerpts 3 and 4, below:

(\#3) It is a book that should teach "the basic notions of Portuguese needed for those who wish to take action, with solid foundations, a fruitful secondary course". (R08_1960)

(\#4) Right from the start, the book makes it very clear for what it came: to disclose one of the theories and methods of Discourse Analysis. (R35_2005)

As the examples above illustrate, the focus of step 1.2 is to indicate the theme addressed to inform the readers what subject the book is about. In addition to present the theme, academic reviews are also carried out through Step 1.3 - Informing about the author. Introducing the book based on this step was a strategy recurrent in the three generations, although a decreasing frequency can be observed during each one of them. In the first generational phase, this step was manifested in $60 \%$ of the texts, while in the second generation the percentage decreased to $53.3 \%$. In the third phase, the data pointed to the presence in $46.6 \%$ of the academic reviews that are part of the corpus, equivalent to the occurrence in 9, 8 and 7 samples in each phase, respectively. The gradual decline of this step can be interpreted as indicating a possible decrease in its social relevance, when compared to the first performances of this genre.

The most common lexical items from this step mention the writer, through terms such as: "professor", "author", "collaborators", in addition to the proper names of these scholars. This observation can be seen in the following excerpts:

(\#5) We point out among the collaborators two professors from the University of Paraná, Mansur Guérios (Portuguese language) and Pinheiro dos Reis (Romanic Philology). (R01_1953)

(\#6) A contribution in this regard is the work translated into Portuguese and recently launched in Brazil called The Linguistic policies, by Louis-Jean Calvet, professor of Sociolinguistics at the University of Provence, France. (R39_2009)

In continuity with the information about the authors described and illustrated earlier, academic reviews, in the three generations, also presented Step 1.4 - Informing potential readership. With regard to regularity, we noticed that this element was manifested in $60 \%$ of the samples in the first 


\section{REVISTA DA ABRALIN}

generational group, in $33.3 \%$ of the second group and in $40 \%$ of the third one. This finding suggests that, among the reviews published in the years of 1953 and 1970, the indication of the audience seemed to have a greater relevance in the constitution of the genre. This is possibly due to the fact that, during this period, many of the publications were difficult to access and, therefore, reviewers usually indicate, with greater frequency, the targeted audience of certain publications, in order to direct the readers to books of their interest:

(\#7) Saying that the pretensions of his book were modest, Gladstone Chaves de Melo intended it "for Portuguese teachers who could not have a college degree" (...) However, even the people specialized in these studies will be able to gather new guidelines for their teaching practices. (R03_1954)

The example illustrated in \#7 is an excerpt from the first generational phase, in which many reviews were dedicated to teachers in basic education schools, or even to notorious-knowledge teachers, that is, who did not have college education due to the difficulty to access higher education. In the three generations, however, academic reviews also used to recommend the works analyzed for professors and college students.

In addition to Step 1.4, we also identified Step 1.5 - Informing about the origin of the book, which appears in less than half of the samples. The textual portions that express it were registered in 5 academic book reviews of the first generation (33.3\%), in 4 texts of the second (26.6\%) and in 5 of the third (33.3\%). Araújo (1996), who first defined this step, presented it as a rhetorical artifice characteristic of academic reviews that examined collections. However, in our analysis, we found that information about the origin is also frequent in reviews produced about books signed by a single author.

This rhetorical step is also carried out through informational units such as the following:

(\#8) The linguistic lessons from professor Câmara Júnior were first published in the "Revista de Cultura", from Rio, in 1939-1941, and later improved and expanded, they were present in the issue with the same title above, edited by F. Briguiet \& Cia., Rio, 1942. (R02_1954)

(\#9) Work by Dominique Maingueneau launched in France in 1984, which now has its version in Portuguese through the translation of Sírio Possenti and the publication by Criar Edições, from Curitiba. (R38_2008)

The main attribute of this step concerns the fact that it has disseminated information about the historical context of the publication, indicating the period of publication, information about editors, translators or, even, related to the publishing companies and the place of publication.

The last rhetorical component referring to the ways in which Move 1 was carried out was Step 1.6 - Inserting the book in the field. This sixth compositional element presents, as its main

\footnotetext{
${ }^{8}$ Journal of Culture
} 


\section{REVISTA DA ABRALIN}

argumentative strategy, the description of in which field of knowledge the work reviewed is inserted and how the book fills a gap in this area.

This step was found in 8 samples of generational phases 1 and 2, that is, in $53.3 \%$ of the academic reviews referring to these historical periods. Contrary to the trend of the other informational units that constitute the Move 1, this step of the rhetorical structure presented a higher frequency in the data of the third generation, appearing in $60 \%$ of the samples. The ways of carrying it out occur very similarly in all generations. Sample 10 can summarize it:

(\#10) The importance of this work, in the field of Applied Linguistics, can be attributed to the fact that it is the first work published in Brazil's editorial market to bring practical and systematic activities with the use of corpora for the teaching of the English language in the Brazilian educational context. (R45_2015)

Examples with this content were present in the three generations, which revealed a similar way to perform, that is: informing that the book fills gaps in the field of knowledge and that it presents innovations when compared to previous works.

Once we finished the discussion of Move 1, as well as its respective steps, from now on, we will present the description of Move 2 - Summarizing the content.

\subsection{Move 2 - Summarizing the content}

Move 2 - Summarizing the content concerns the description, synthesis and discussion of content conveyed in the book. Considering its characteristics, we noted that it is an essentially descriptive rhetorical move, in which the reviewers outline aspects concerning the organization of the book, the topics that are addressed, the methodology and extra-text aspects. As shown in Chart 6, Move 2 consists of 5 steps. The first one, Step 2.1 - Describing the overall organization, showed an incidence in $53.3 \%$ of the first-generation samples, $73.3 \%$ in the second generation and $66.6 \%$ in the third one.

It can be said that the description of general organization of the book and the ways of carrying out this description do not manifest evident changes in the diachrony of academic reviews in terms of argumentative strategies used by the reviewers as they typically present how the book is presented in terms of general organization:

(\#11) The book has the following disposition: Chapter I - Origins of the language, pp. 1-51; Chapter II - Old High German, pp. 52-132; Chapter III -Middle High German, pp. 133-227; Chapter IV - Transitional Period, pp. 228257; Chapter V - Modern German, pp. 258-315; Chapter VI - Word formation, pp. 316-334; Chapter VII - Syntax in modern German pp. 335-425; Bibliography, pp. 426-434. (R12_1963) 


\section{REVISTA DA ABRALIN}

(\#12) The book consists of eleven chapters, four of which describe the cognitive processes of general domain that act in structuring of the language. The remaining seven chapters deal with different aspects linked to an integrated theory of language use and linguistic change. At the end of each chapter, the author summarizes the main points discussed, which facilitates the understanding of the material read. (R43_2013)

To inform about the disposition of the book, the reviewer continues this descriptive rhetorical action from the presentation of the book's content with Step 2.2 - Presenting the topics of the book found in most of the samples gathered. Its recurrent mobilization in the structure of the genre can be seen as a result of its social relevance and presented increasing rates. Step 2.2 has been verified in $53.3 \%$ of samples of the first phase, in $60 \%$ of texts of the second and in $93.3 \%$ of the third. This percentual is equivalent to the occurrence in 8,9 and 14 review, respectively. These data reveal its greater prototypicality in the reviews published between 2000 and 2015, indicating the importance that rhetorical actions of a descriptive nature can play in the most recent reviews.

This second step from Move 2 diverges from the one previously described in the way that, while Step 2.1 presents the general organization of the book, Step 2.2 concerns the description of themes, concepts that may be of interest to potential readers on specific pages or sections of the book. In our analysis, we observed that the rhetorical action of describing specific parts of the book does not always concern the general description of the work - the rhetorical action that consists of Step 2.1.

With this observation, we report to some excerpts that illustrate this Step 2.2:

(\#13) On page 76. J. K. concludes part of his considerations on the narrative aspect, remembering that the dialogical discourse comprehends three types: the one from carnaval, the one from menippe and the one from the novel (polyphonic). (R17_1975)

(\#14) In chapter I, "In the origins of the linguistic policy", Calvet exposed the emergence and evolution of the binomial policy and linguistics planning in the second half of the 20th century, seeking to correlate with some political challenges of that time. (R39_2009)

The two samples illustrate cases in which certain topics of the work are described in a more particular way: in sample 13, illustrating the page on which a content is addressed and, in sample 14, presenting the description of a specific chapter. These cases present the two most common ways of performing the Step 2.2. In addition to it, and complementarily, we highlight Step 2.3 - Discussing the content of the book. We consider that the strategy of discussing content differs from the rhetorical action of presenting the topics of the work.

We understand that the act of discussing is related to the exposure of a deeper analytical look in which the reviewer displays the points of view, establishes relationships with others studies or even exemplifies and didacticizes the content. This rhetorical component appeared in $60 \%$ of the texts in the first group, $86.6 \%$ in the second and in $93.3 \%$, in the third. 


\section{REVISTA DA ABRALIN}

These numbers mean that Step 2.2 had a lower number of occurrences than Step 2.3 in generational phases 1 and 2 . This may indicate that the most recent reviews may be more argumentative than the older ones. Examples appear below:

(\#15) In this point of view we disagree a little with the Author, who is, in our view, a little too intransigent; the experience has not shown us enough yet, but it may prove that reasonable exercises of version can be of great help in acquiring good grammatical, lexical and stylistic knowledge on the part of students. (R10_1960)

(\#16) One of the points highlighted by Calvet (attribution) is that there must be a "language equipment", in the sense that they are equipped with necessary and sufficient resources to fulfill certain functions assigned by the State. An example of this is what happens in Brazil with indigenous languages since the 1988 Constitution and the 1996 National Education Guidelines and Bases Law. (R39_2009)

The examples presented show us that, in the step under discussion, the reviewers relate ideas, discuss the content based on comparisons, disputes, convergences and the exemplification of what is exposed in the reviews work. For this to happen, the reviewer can either refer to the discourse of the author of the book or express his own positions.

In continuity with this critical-descriptive character, we also identified Step 2.4 - Reporting the methodology, which had not been observed in previous studies on academic reviews. Its frequency, however, was not high, appearing in $46.6 \%$ of generation 1 samples, declining to $13.3 \%$ and $20 \%$ in generations 2 and 3 , respectively.

We consider it pertinent to discuss this constituent of the genre because we observed a considerable presence, especially, in the first generational phase. In the reviews of that period, we found that the methodology was known from the methodological aspects and the categories addressed by the authors in their books, especially in reviews that analyzed works that published research results:

(\#17) To arrive at this reconstitution, he applied the only viable method in similar research: the historical-comparative one. [...] Starting from the conformity between the Romanic Languages, inductively, it reaches the previous stage of these languages and gets the confirmation of the results obtained through the writers' texts, the information of the Latin grammarians and through the Latin epigraphy. (R09_1961)

As we informed, this step appeared less frequently in the following generations, manifesting itself in passages when the reviewers felt the need to describe the methodological aspects that supported the approach of the reviewed book:

(\#18) The work is, according to A.'s words, within a historical-comparative scheme. [...]. With regard to methodology, the work, which is essentially structuralist in nature, does not deviate much from traditional models of historical description of linguistic phenomena. (R20_1981) 


\section{REVISTA DA ABRALIN}

(\#19) Using the approach known as Used-Centered Linguistics (Usage-based Theory), Bybee seeks to explain the essence of grammar, focusing on its variant and gradient character. Consistent with the theoretical posture she adopts, the author bases her studies on extensive corpora of spoken and written language, applying a consistent set of hypotheses to phonology, morphosyntax and semantics. (R43_2013)

This descriptive bias goes through all of Move 2 and it is also emphasized in Step 2.5 - Citing extra-text material, component that is equally descriptive, although it may be linked to evaluative postures. Its percentage indexes suggest that it is an unusual rhetorical device, used in less than half of academic reviews published. We verified its occurrence in 3 samples (20\%) of the first phase, 2 samples (13.3\%) of the second phase and in 4 samples (26.6\%) of the third. This rhetorical unit was first cataloged by Motta-Roth (1995) to refer to reviewing parts of the book that did not concern the main content of the genre. In this case, the extra-text material that is cited focuses mainly on pretextual and post-textual elements, or even physical characteristics of the work examined by the reviewer:

(Sample 20) The outline of the work is presented in the preface. [...]. An explicative note justifies this subdivision. The author regrets that he can not go beyond das generalities, since syntax has always been treated superficially, both in expository and historical grammars. (R09_1961)

(Sample 21) The book comes with a hardcover and book jacket in paper. On the book jacket, on the back page, there is a general presentation of the work and information about the organizers. (R40_2010)

Excerpts show that the reviews also describe aspects that are not necessarily related to the thematic content of the books. In addition, the data from our research certify that, more than outlining extratextual parts of the book, as already pointed out by other studies, step 2.5 also manifests axiological postures when attributing positive properties to the book. As we have shown throughout this analysis, evaluative positions are present in all moves of this genre. However, we understand the evaluation also appears as a centralized resource that reveals the reviewer's subjectivity, as we will discuss in the analysis of the next move.

\subsection{Move 3 - Evaluating the book}

With fewer rhetorical steps than the previous ones, the Move 3 - Evaluating the book, presents a critical exam of the book through evaluative comments on the book itself, as well as on its specific parts, in addition to presenting possible suggestions for improving the work. This move signals a shift from the rhetorical action on content description, typical of Move 2, to a more explicit criticalargumentative posture. 


\section{REVISTA DA ABRALIN}

Step 3.1 - Providing general assessment, for example, contemplates occasions when the reviewer promotes a general criticism about the book as a whole. At the beginning of its circulation in the field of Linguistics, general evaluations of the book were performed in 6 texts of Phase 1, that is, in $40 \%$ of cases. The next generation shows the permanence of this unit in 13 samples, equivalent to updating in $86.6 \%$ of the reviews in the period. In Phase 3 , despite an evident decrease in relation to the previous phase, we still noticed a high occurrence, in 11 texts, reaching the frequency of $73.3 \%$.

(\#22) What most impresses, undoubtedly, in Professor Bahamani's work, is the effort to be clear and exhaustive. A clarity is witnessed in the impeccable presentation of the four volumes, in the organization of the content of each volume. (R25_1991)

(\#23) The book is presented in a well-careful format, showing excellent internal organization interna. The letters, the layout, the paper, etc. show special care with the setup of the book. The translation of the work is of excellent quality. (R40_2010)

In our study, however, we observed two types of evaluation. Besides the general assessment of the book as a whole, described in Step 3.1, we identified Step 3.2 - Providing focused assessment. Its incidence was more typical in Phase 1, detected in 9 samples, which add up $60 \%$ of frequency. In Phase 2 the opposite happens, since the assessment focused on a given aspect was recurrent in 6 texts, that is, it was present in $40 \%$ of the academic reviews gathered, a lower number than the one of the criticisms of the overall structure of the publication. This characteristic is preserved in the third phase, being present in 7 texts, totalizing $46.6 \%$ of the occurrences. The evaluative focus described in Step 3.2, therefore, is to specifically criticize some passages, such as book chapters:

(\#24) This chapter and the first of the work in question, although of great linguistic interest, are the ones with the least original contribution, since they disseminate widespread ideas in General Linguistics, as well as in previous works by the author. (R16_1971)

The sample 24 illustrates and summarizes the main ways of implementing this rhetorical component, since Step 3.2 is a step in which the reviewer critiques specific chapters, sections or parts of the book. On other occasions, however, the reviewer highlights some points that need to be revised in the book, as it happens in Step 3.3 - Presenting suggestions for improvement also identified in our analysis. This rhetorical-compositional strategy, taken from the model by Araújo (1996), is not found in prototypes by other researchers and, even in the study of this author, it was identified only in a few samples.

Despite this, we described and included this step as a characteristic of the rhetorical structure of reviews in the Languages and Linguistics field in Brazil. Thus, we point out the percentage in which it appears, given that we detected it in seven samples (46.6\%) from Phase 1, five texts (33.3\%) from Phase 2 and in three (20\%) from Phase 3. These numbers reveal that, in the diachrony of this 


\section{REVISTA DA ABRALIN}

step, there is a decline in the number of occurrences, since, in each generation, it has been running at increasingly lower rates.

Spite of this decrease, the textual portion that expresses suggestions for improving the book contribute to the evaluation of the academic material in a specific way, as well as show the reviewer's concern with the scientific production in the field, suggesting characteristics to be reformulated, as we can see in the excerpt 25:

(\#25) Some aspects could deserve additions or modifications in a possible reissue [...] a list of suggested parallel readings - that is, a brief list of commented bibliographic references - would further contribute to the didactic value of the work. (R29_1999)

The presence of Step 3.3 reinforces the interpretation that the social objectives of reviews are not only related to the description and recommendation of a book. Through suggestions, the reviewer collaborates with the development of language studies based on constructive criticism, that aim the improvement of the studies in the field.

This critical and evaluative posture also stands out, in the last rhetorical unit we have described. Move 4 - Issuing a final opinion, that promotes a final analysis of the work, aiming its recommendation or disqualification. In addition to the statements concerning the opinion on whether the work is or not valid reading, we point out in this last move the presence of a rhetorical strategy typical from phase 1 , in which the reviewers end their texts expressing cordiality to the authors of work that they reviewed.

\subsection{Move 4 - Issuing a final opinion}

Move 4 - Issuing a final opinion is divided into two rhetorical steps. The first one, Step 4.1 - Recommending/disqualifying the book, manifested itself in 5, 10 and 14 samples, respectively. In percentage indexes, it appeared in $33.3 \%$ of the texts that set Phase 1 , in $66.6 \%$ of the samples in Phase 2 , and in 93.3\% of the academic reviews gathered for Phase 3 .

As we are based on the assumption that the genre reflects characteristics of the social situations that originate it, we can interpret that the rhetorical action of recommending (or not) the book seems to be more significant in recent reviews. In addition to that, the data obtained from the analysis of our corpus point to the presence of evaluative postures both favorable and unfavorable to the reading of the reviewed book:

(\#26) In our view, the work reviewed here presents a valuable contribution and can be considered a must-read for both teachers and students of Language Teaching Practice. (R28_1998) 


\section{REVISTA DA ABRALIN}

(\#27) The conclusion is somewhat sad: a laudable initiative by the publisher ended up being rendered useless by an unfortunate choice, and the least that can be said is that the gap remains as serious as before - or perhaps more, because of this type of gap it can be said that it is better blank than poorly filled. (R34_2004)

Motta-Roth (1995) and Bezerra (2001), when discussing the recommendation of books in academic reviews, propose that the Recommendation/disqualification of the book can unfold another rhetorical step: Recommending the book despite indicating limitations. Our data showed that this distinction would be unproductive to the analyzed reviews, given that we identified cases like these only in one sample from Phase 1, two from Phase 2 and none in Phase 3. Therefore, we kept Step 4.1 called recommending/disqualifying the book. In the second and third generation, this is the textual item that traditionally concludes the review.

However, in the first generation we found another unit that, although it was relevant at the time it was published, has been disappearing diachronically. Step 4.2 - Expressing wishes for future publication, draws our attention because even though it has not been cataloged in other studies on this genre, it is configured as a traditional element of the first generational phase. This component is textualized by a short statement in which the reviewer expresses the desire that the works of the author are fruitful and have continuity such as the \#28 example highlighted:

(\#28) I submit these considerations to Herculano de Carvalho as a modest contribution to his valuable study, and I close this Review with the hope that we will soon have the following volumes, which together will give the scientifically modern version of the curious language of Miranda's Land. (R06_1959)

These wishes were expressed, probably, as a way of providing an academic incentive so that publications in this field of studies, under development at the time, were not interrupted and the language scholars continued to make contributions to the area in a period of low productivity and search for the consolidation of Linguistics in the Brazilian academy. This Step 4.2, also, creates a social representation of the reviewer as a concerned member that the studies in his area will continue in full development.

This proves a series of changes and permanencies in the rhetorical structure of academic reviews of Linguistics. The traditions of each historical phase reveal specificities in the percentage indexes in which each move and step. Following these evidences, we finished our study on this investigative object. We intend to show, through the analysis presented in this article, that the academic book review is as a genre that has undergone different changes and also reveals some enduring features that do not change from one generation to another.

In this sense, our goal was to present both transformations and traces of permanence in the historical course of the review over 62 years. In the following conclusion, we return to some aspects raised and summarize the results of this historical-comparative study. 


\section{REVISTA DA ABRALIN}

\section{Conclusion}

This research aimed to analyze vestiges of change and traces of permanence in the academic book review through the examination of samples produced between the $20^{\text {th }}$ and $21^{\text {st }}$ centuries. We expected to illustrate that each historical phase reveals specificities in the percentage indexes in which each rhetorical move and step appear. In terms of diachronic erasure, we examined that Step 4.2 - Expressing wishes for future publication, typical of Phase 1, does not reveal any permanence features.

Items such as Step 1.3 - Informing about the author and Step 3.3 - Presenting suggestions for improvement, although recurrent in all phases, also show a decreasing continuum, since they have percentage indexes that gradually decrease in each generational period. On the other hand, in other components, as in the case of Steps 2.2 - Presenting the topics of the book; 2.3 - Discussing the content of the book and 4.1 - Recommending/disqualifying the book, we realized that each generation reveals a greater frequency of these rhetorical elements, suggesting that their social relevance has increased at the same time as its linguistic updating becomes more frequent.

In short, our interest was to show these differences in organizational patterns, in order to understand the genres, which are not ready and finished objects, are precisely in constant update in our society, are mutable - although, naturally, they retain several characteristics. We hope, therefore, that this investigation might be considered valid by those who understand and recognize the need for new theoretical and methodological practices to analyze the genres, especially in a diachronic perspective.

We also know that no research exhausts the investigative possibilities of its object and, therefore, we are aware that our study evokes many other questions that may be addressed in researches to come. Thus, we hope that the next studies will continue the work we started here.

\section{REFERENCES}

ARAÚJO, A. D. Academic genres in university contexts: an investigation of students' book reviews writing as classroom assignments. In: BAZERMAN, C. et al. (Orgs.) International advances in writing research: cultures, places, measures. Fort Collins: The WAC Clearinghouse; Anderson: Parlor Press, 2011, p. 319-334.

ARAÚJO, A. D. Lexical signalling: a study of unspecific-nouns in book reviews. 1996. 274f. Tese (Doutorado em Letras-Inglês) - Programa de Pós-Graduação em Letras-Inglês, Universidade Federal de Santa Catarina, Florianópolis.

ASKEHAVE, I.; SWALES, M. J. Identificação de gênero e propósito comunicativo: um problema e uma possível solução. In: BEZERRA, B. G.; BIASI-RODRIGUES, B.; CAVALCANTE, M. M. (Org.). Gêneros e sequencias textuais. Recife: Edupe, 2009, p. 221-247.

BEZERRA, B. G. A distribuição das informações em resenhas acadêmicas. 2001. Dissertação (Mestrado em Linguística) - Programa de Pós-Graduação em Linguística, Universidade Federal do Ceará, Fortaleza, 2001. 


\section{REVISTA DA ABRALIN}

CASTILHO DA COSTA, A. Tradições discursivas em A Província de São Paulo (1875): gêneros textuais e sua constituição. In: Anais... Simpósio Mundial de Estudos de Língua Portuguesa, 2008, São Paulo. p.1-27.

CIAPUSCIO, G. E. Tradiciones discursivas y variación diacrónica de los gêneros académicos: el artículo de investigación em la filologia y la lingüística de la Argentina. In: CIAPUSCIO, G. E. et al. Sincronía y diacronía de tradiciones discursivas en Latinoamérica. Frankfurt: Vervuert, 2005, 13-25.

COSERIU, E. O homem e sua linguagem. São Paulo: Editora da Universidade de São Paulo, 1980.

GIL, A. C. Métodos e técnicas de pesquisa social. São Paulo: Atlas, 2008.

KABATEK, J. Prólogo. In: COSERIU, E. Lenguaje y discurso. Pamplona: EUNSA, 2006, p. 09-12.

MOTTA-ROTH, D. Rhetorical features and disciplinary cultures: a genre-based study of academic book reviews in linguistics, chemistry and economics. 1995. 365f. Tese (Doutorado em Letras-Inglês) - Programa de PósGraduação em Letras-Inglês, Universidade Federal de Santa Catarina, Florianópolis, 1995.

PALTRIDGE, B. Análise de gêneros e a identificação de fronteiras textuais. In: BEZERRA, B. G.; BIASI-RODRIGUES, B.; CAVALCANTE, M. M. (Orgs.). Gêneros e sequências textuais. Recife: EDUPE, 2009, p. 61-78.

SWALES, J. Genre analysis: English in academic and research settings. Cambridge: Cambridge University Press, 1990.

ZAVAM, A. S. Por uma abordagem diacrônica dos gêneros do discurso à luz da concepção de tradição discursiva: um estudo com editoriais de jornais. Tese (Doutorado em Linguística) - Programa de Pós-Graduação em Linguística, Universidade Federal do Ceará, Fortaleza, 2009. 